\title{
PKM Pemasaran Sosial Media Berbasis Mobile Dalam Rangka Membantu Keterbatasan Ruang Gerak Selama Pandemi Covid-19
}

\author{
Miguna Astuti*1, Nurhafifah Matondang² \\ 1Program Studi Manajemen, Fakultas Ekonomi dan Bisnis, UPN Veteran Jakarta \\ ${ }^{2}$ Program Studi Teknik Informatika, Fakultas Ilmu Komputer, UPN Veteran Jakarta \\ *e-mail: miguna.astuti@upnvj.ac.id ${ }^{1}$, nurhafifahmatondang@yahoo.com²
}

\begin{abstract}
Partners in PKM are the PAGODA Women's Group (KWP) in Kp. Cigundi, Kec Cibadak, Lebak, Banten. However, the condition of Kp. Cigundi itself is still a cause for concern. Most of Partner members already have cell phones with access, but Partners have not used HP to promote their Groups, Villages and Enye-Enye products. Partners in this program produce Enye-Enye in a simple packaged semi-finished form. Mitra does not produce Enye-Enye for commercial purposes. Enye-Enye has also been recognized as a typical product of Mekaragung village, but the income from Enye-Enye products is not obtained because the partner deliberately sells, so it can be concluded in the early PKM, namely (1) Increased partner knowledge on their organizational concept up to $88 \%$, up to $92 \%$ on their product quality, price and packaging knowledge, and up to $84 \%$ on their promotional activities knowledge. (2) Overal increased partner skills by $88 \%$ including their organizational skills, product quality, pricing and promotional skills and also their skills in utilizing their mobile phone/smartphone for their organizational needs product quality, pricing and packaging researches, and also for promoting their products (Crisp Enye-Enye) (3) Increased income of KWP members to 294\%, much higher than the initial target of only $100 \%$.
\end{abstract}

Keywords: Enye-Enye, Social Media Marketing, Mobile, Cigundi Village

\begin{abstract}
Abstrak
Mitra dalam PKM adalah Kelompok Wanita PAGODA (KWP) di Kp. Cigundi, Kec Cibadak, Lebak, Banten. Namun kondisi Kp. Cigundi sendiri masih tergolong memprihatinkan. Sebagian besar anggota Mitra telah memiliki HP dengan akses, namun Mitra belum memanfaatkan HP untuk mempromosikan Kelompok, Kampung serta produk Enye-Enye mereka. Mitra dalam program ini memproduksi Enye-Enye dalam bentuk setengah jadi yang dikemas secara sederhana,Mitra tidak memproduksi Enye-Enye tersebut untuk tujuan komersial. Enye-Enye ini juga telah diakui sebagai produk khas desa Mekaragung, namun pendapatan dari produk Enye-Enye diperoleh bukan karena Mitra sengaja menjual, sehingga dapat disimpulkan dalam PKM ini yaitu (1) Meningkatnya pengetahuan mitra mencapai hingga sebesar 88\% terkait kelembagaan, 92\% kualitas produk, harga dan kemasan, 84\% untuk kegiatan promosi. (2) Meningkatnya keterampilan mitra sebesar 88\% terkait kelembagaan, kualitas produk, harga, kemasan dan promosi serta penggunaan telepon seluler untuk peningkatan kualitas pelaksanaan kelembagaan, riset untuk peningkatan kualitas produk, harga, kemasan dan promosi (3) Meningkatnya pendapatan anggota KWP menjadi 294\%, jauh lebih tinggi dari target awal yang hanya $100 \%$.
\end{abstract}

Kata kunci: Enye-Enye, Pemasaran Media Sosial, Mobile, Kampung Cigundi

\section{PENDAHULUAN}

Usaha mikro, kecil dan menengah (UMKM) memiliki porsi yang signifikan dalam menyumbang jumlah PDB Indonesia serta menyerap tenaga kerja (Afandy, 2010). Didik J Rachbini, seorang ekonom Indef menyatakan bahwa daya saing komoditas produk di Indonesia masih kurang. Hal tersebut dikarenakan kecenderungan Indonesia yang melempar barang ke pasar dalam keadaan mentah (Ghozali Khakim, 2011). Lebih lanjut, dinyatakan pula bahwa campur tangan iptek dalam menyuntikan nilai tambah terhitung kecil, membuat produk lokal di Indonesia menjadi kurang kompetitif (Gangeshwer, 2013). Rendahnya jumlah konsumsi produk lokal tersebut kemudian akan berimbas pada menurunnya pendapatan pengusaha lokal, dalam hal ini UMKM yang kemudian akan menurunkan kontribusi UMKM terhadap PDB serta menurunkan pula serapan tenaga kerja dan meningkatnya angka pengangguran (Alimudin \& Sasono, 2015). 
Salah satu cara untuk meningkatkan pendapatan UMKM adalah dengan memanfaatkan media internet sebagai sarana promosi. Peluang yang besar atas pemanfaatan media internet sebagai sarana promosi ini adalah atas dasar data penggunaan internet di Indonesia (Pradipta, 2018). Pengguna internet di Indonesia saat ini mencapai 171,18 juta orang dan berada pada peringkat ke-6 di dunia (APJII, 2018). Dari jumlah tersebut pengguna internet terbesar tercatat berada di Pulau Jawa, dengan Provinsi Jawa Barat sebagai penyumbang penetrasi terbesar yaitu sebanyak 41,7 persen. Wilayah Banten sendiri mencatat jumlah pengguna internet mencapai 35 persen. Badan Pusat Statistik (BPS) bahkan mencatat bahwa sebanyak 94,4 persen warga Banten melakukan aktifitas internet melalui telepon seluler atau handphone (HP) . Dari sisi penggunanya, terungkap bahwa penggunaan smartphone (ponsel) menjadi alat yang sangat dominan sebagai alat untuk akses internet setiap hari, yakni mencapai 93,9\% dan ruang pubik $(29,5 \%)$. Dari data yang tersaji itu, penetrasi internet yang tinggi diyakini bisa menjadi menjadi instrumen untuk pertumbuhan ekonomi satu negara. Melalui medium internet, banyak peluang yang bisa diciptakan, diinovasikan, penyebaran pengetahuan, peningkatan kemampuan konsumen, serta membangun jaringan serta mengelola interaksi social (Nurhanisah, 2019).

Dipasangkan dengan maraknya pertumbuhan UMKM di wilayah Banten, penggunaan internet di wilayah ini sebanyak 80,45 persen adalah hanya untuk mengakses sosial media (Darussalam, 2018). Sedangkan yang memanfaatkan internet untuk kegiatan ekonomi tidak mencapai 10 persen (APJII, 2018). Padahal internet dapat memberikan banyak manfaat bagi pelaku UMKM, diantaranya yang paling utama adalah untuk meningkatnya penjualan melalui proses pemasaran (Febriyantoro \& Arisandi , 2018). Manfaat internet lainnya bagi pelaku UMKM antara lain adalah sebagai media branding produk, untuk memahami konsumen dengan lebih baik, memperluas target pasar, dan masih banyak lagi (Nurmalasari, 2020). Lebih lanjut, Usaha Mikro Kecil dan Menengah (UMKM) Lebak Sejahtera terus berupaya agar bisa maju dan sejahtera. Salah satu upaya yang dilakukan adalah memasarkan produk-produk UMKM lokal agar lebih dikenal masyarakat. (Ali, 2019)

Dari hasil survei pada beberapa pelaku UMKM di di kabupaten Lebak, Banten, diketahui hal serupa juga terjadi, dimana pelaku UMKM tidak memanfaatkan telepon seluler serta akses internet yang mereka miliki untuk memajukan usahanya. Demikian juga pelaku UMKM kuliner diwilayah ini, termasuk mitra PKM, yaitu Kelompok Wanita PAGODA (KWP).

KWP merupakan kelompok wanita yang beroperasi di kampung Cigundi, desa Mekaragung, Kecamatan Cibadak, Kabupaten Lebak, Banten. Kelompok ini terdiri dari para ibu rumah tangga yang berdomisili di desa Mekaragung, terutama mereka yang berada di kampung Cigundi. Pada awalnya, wancana dibentuknya kelompok ini adalah sebagai wadah berkumpulnya para istri dari anggota Kelompok Surya Tani (KST) yang juga beroperasi di Kampung Cigundi. Ketua KST, yaitu Bapak Dedi mendukung istri-nya yaitu Ibu Susi untuk mempelopori berdirinya KWP ini di awal tahun 2000. Organisasi non formal ini didirikan oleh Ibu Susi atas dasar kesamaan kepentingan, kondisi lingkungan, sosial eonomi dan sumber daya serta terutama berdasarkan keakraban. Sampai hari ini Ketua dari KWP adalah Ibu Susi, sedangkan struktur organisasi dari KWP sendiri belum ada. Hingga saat ini, KWP belum memiliki struktur organisasi serta jobdesk dan hanya ketua (Ibu Susiyawati) yang aktif menggerakkan Ibu-Ibu KWP setiap diadakan kegiatan.

Berkat luasnya lahan pertanian dan perkebunan di Desa Cigundi serta bantuan bibit Singkong dari dinas pertanian, hampir seluruh ibu Rumah Tangga yang berada di Desa Mekaragung telah mengolah kelebihan panen Singkong mereka menjadi makanan olahan setengah jadi yang dikenal dengan istilah Enye-Enye. Singkong di Kabupaten Lebak hingga kini menjadikan andalan pendapatan ekonomi petani sehingga menyumbangkan kesejahteraan kehidupan mereka (Antara, 2020)

Tidak lama, Enye-Enye ini menjadi salah satu produk unggulan dari wilayah ini. Meski lahan untuk menanam Singkong di Kampung Cigundi cukup luas, namun Mitra menyatakan bahwa Sebagian besar petani di kampung Cigundi menanam Singkong untuk dikonsumsi sendiri, 
dan tidak untuk di jual secara komersil. Disampaikan pula bahwa selama musim kemarau, EnyeEnye tidak dibuat karena Singkong di ladang seringkali dijadikan cadangan bahan makanan utama oleh pemilik lahan (karena kuatir tidak punya beras untuk makan selama musim kemarau). Demikian juga selama Pandemi Covid-19, hamper tidak ada petani Singkong di Kampung Cigundi yang bersedia menjual Singkongnya, apalagi mengijinkan para istri (yang juga anggota KWP) untuk membuat Enye-Enye dari Singkong tersebut.

Sebelum dibentuknya KWP, Enye-Enye yang diproduksi oleh ibu-ibu di Kampung Cigundi ini juga hanya dimanfaatkan untuk makanan cemilan pada saat tamu berkunjung (perwakilan Dinas Peternakan, Kepala Desa, Camat, Asisten Daerah Lebak, sanak saudara, dsb). Namun Ibu Susi yang melihat kesempatan dan nilai dari Enye-Enye ini kemudian bekerja sama dengan ibuibu Cigundi untuk memproduksi Enye-Enye dengan tujuan untuk dijual/dititipkan di warungwarung sekitar Desa Mekaragung. Enye-Enye dari KWP dijual masih dalam bentuk setengah jadi dan masih harus digoreng terlebih dahulu sebelum dapat dinikmati. Kemasan dari Enye-Enye ini juga masih tradisional, dimana lembaran Enye-enye diikat dengan tali rapiah dan dimasukkan ke dalam plastik ukuran 1 kilogram dan diselipkan label kecil fotokopian berwarna hitam-putih yang tidak menarik, lalu kemudian disegel dengan bantuan api kecil dari lilin, adapun bentuk dari kerupuk serta kemasan.

Terlihat bahwa Enye-Enye hasil produksi mitra (KWP) dari kampung Cigundi, Kabupaten Lebak, Banten mengalami permasalahan terkait manajemen dan pemasaran terutama terkait bagaimana mengatasi keterbatasan akses informasi manajemen dan pemasaran tersebut melalui telepon seluler/Handphone/Mobile. Adapun permasalahan-permasalahan yaitu rendahnya kemampuan berorganisasi/kelemagaan mitra, Produk Enye-Enye masih diproduksi dalam bentuk setengah jadi dengan kualitas produk, harga, dan kemasan yang masih rendah, Rendahnya kemampuan Mitra terkait pemanfaatan telepon seluler serta akses internet yang dimiliki dalam memperbaiki kelembagaan/organisasi dan kualitas Enye-Enye dan Rendahnya kemampuan Mitra dalam berpromosi, serta menggunakan pemasaran media sosial berbasis mobile sebagai wadah promosi Enye-Enye dalam mengatasi keterbatasan akses usaha.

Seperti telah diuraiakan di atas, terdapat 4 permasalahan utama dari Mitra. Untuk mengatasi permasalahan yang muncul dari kelompok Mitra perlu diadakannya Pelatihan dan pendampingan penguatan kelembagaan/organisasi, Pelatihan dan pendampingan peningkatan kualitas produk, harga dan kemasan, Pelatihan dan pendampingan pemanfaatan telepon seluler dalam memperbaiki kelembagaan/organiasi dan kualitas, serta Pelatihan dan pendampingan kegiatan promosi serta menggunakan pemasaran media sosial berbasis mobile sebagai wadah promosi bagi Kampung Cigundi, Kelompok Wanita Pagoda (KWP), dan Enye-Enye.

\section{METODE}

Metode pelaksanaan kegiatan Pengabdian kepada masyarakat ini berupa kombinasi berupa metode analisis yang dilaksanakan secara bersama antara tim Pengabdian dengan Mitra UKM Kecamatan Cibadak dan 3 individu (pelaku UKM) kerupuk enye-enye di Desa Mekaragung yang berada di bawah naungan Kelompok Wanita Pagoda, serta penyusunan luaran kegiatan berdasarkan hasil analisis bersama-sama pula. Metode yang mengikutsertakan mitra tersebut disebut juga dengan metode partisipatif. Adapun digunakannya metode ini adalah agar Mitra juga memberikan kontribusi dalam peningkatan kinerja usahanya. Dengan demikian, diharapkan luaran kegiatan yang dihasilkan dapat dimanfaatkan dengan baik serta berkelanjutan oleh Mitra. Adapun tahapan kegiatan abdimas ini terdiri atas:

a. Tahap persiapan,

Pada tahap ini selain mengurus perijinan awal, tim pelaksana melakukan survei awal kepada Mitra untuk mendapatkan informasi yang lebih mendalam. Hasil survei termasuk pada diperolehnya permasalahan Mitra yang perlu segera diselesaikan. Untuk menyelesaikan permasalahan ini, maka dilakukan persiapan-persiapan untuk melakukan kegiatan pelatihan dan pendampingan kepada Mitra yang terdiri atas Ibu-Ibu Rumah Tangga yang berdomisili di 
Kampung Cigundi, Desa Mekaragung, Kecamatan Cibadak, Kabupaten Lebak, Banten. Tahap persiapan ini juga dilakukan agar Mitra dan pihak terkait lainnya mendukung sepenuhnya program PKM ini.

b. Tahap pelaksanaan (pelatihan dan pendampingan)

Kegiatan yang akan dilaksanakan pada program PKM ini yaitu:

1. Pelatihan dan pendampingan penguatan kelembagaan/organisasi.

2. Pelatihan dan pendampingan peningkatan kualitas produk, harga dan kemasan EnyeEnye.

3. Pelatihan dan pendampingan penggunaan telepon seluler (mobile) dalam melaksanakan aktifitas kelembagaan dan perbaikan kualitas Enye-Enye.

4. Pelatihan dan pendampingan berpromosi serta menggunakan pemasaran media sosial berbasis mobile sebagai wadah promosi

c. Tahap evaluasi kegiatan,

Evaluasi kegiatan program PKM ini dapat dilihat sebagai berikut:

1. Pengetahuan Mitra terkait kelembagaan (peningkatan pengetahuan).

2. Tersusun struktur organisasi beserta jobdesk (peningkatan keterampilan).

3. Pengetahuan Mitra terkait kualitas produk, harga, dan promosi (peningkatan pengetahuan).

4. Diperolehnya Enye-Enye berbentuk keripik (snack) siap santap dengan beragam rasa yang dikemas secara modern dengan merek dan harga yang menarik (peningkatan keterampilan).

5. Kemampuan Mitra dalam menggunakan telepon seluler (mobile). (peningkatan keterampilan)

6. Kualitas pelaksanaan kelembagaan dan manajemen Enye-Enye (peningkatan keterampilan).

7. Pengetahuan Mitra terkait kegiatan promosi (peningkatan pengetahuan).

8. Kampung Cigundi, Kelompok Wanita Pagoda (KWP) dan Enye-Enye lebih dikenal masyarakat luas. Tidak hanya karena adanya Papan Penanda/Papan Iklan, namun juga karena terdaftarnya Mitra dan Enye-Enya pada media sosial berbasis mobile (peningkatan keterampilan dan pendapatan).

\section{HASIL DAN PEMBAHASAN}

Berikut ini hasil kegiatan Program Kemitraan Masayarakat yang berjudul PKM Pemasaran Sosial Media Berbasis Mobile Dalam Rangka Membantu Keterbatasan Ruang Gerak Selama Pandemi Covid-19, yang telah dilakukan melalui berberapa tahap mulai dari Tahap Persiapan, Tahap Pelaksanaan (Pelatihan dan Pendampingan) dan Tahap Evaluasi Kegiatan, beriku ini hasil dan pembahasan selama dilakukannya program kemitraan masyarakat.

Pada tahap persiapan, Tim Pengabdian melakukan perizinan ke beberapa pihak terkait diantaranya Kepala Kecamatan Cibadak yaitu bapak Rahmat, kemudian tim Pengabdian diperkenalkan kepada Kepala kantor desa mekaragung yaitu Ibu Nining Nurulaeni dan pegawai kantor desa Mekaragung yang bernama Bapak Angga dan kepala desa mekaragung yang bernama Ibu Nining Nurulaeni. Dari kantor desa mekaragung bapak Rahmat kemudian mengajak tim ke salah satu kampung didesa mekaragung yaitu kampung Cigundi. Disini Tim di perkenalkan kepada salah satu pelaku UKM yang sekaligus juga termasuk dalam wadah organisasi kelompok wanita tani "Pagoda". Tim diajak ke kediaman ketua kelompok wanita yaitu ibu Susi. Dari pertemuan inilah tim menggali permasalahan-permasalahan serta berdiskusi terkait solusi apa yang dapat tim berikan pada kelompok wanita tersebut.

Berdasarkan diskusi dengan ketua kelompok Wanita Pagoda, Tim kemudian menyusun draft permasalahan-permasalahan terkait manajemen, terutama bagaimana memasarkan produk 
Kelompok wanita pagoda melalui sosial media. Adapun produk tersebut bernama Enye-Enye. Pada kunjungan selanjutnya pada tanggal 18 Maret 2020, tim Pengabdian kembali mendatangi rumah Ibu susi selaku pendiri kelompok umkm yaitu Kelompok Tani surya Tani dan Kelompok Wanita Pagoda. Tim Pengabdian melakukan kunjungan ke desa mitra untuk memberikan sosialisasi pelaksanaan kegiatan Pengabdian, menyerahkan surat izin melaksanakan abdimas dan mendapatkan surat balasan perizinan melaksankan abdimas dari mitra. Selanjutnya Tim berkoordinasi dengan Kelompok Wanita Pagoda untuk membicarakan teknis pelaksanaan kegiatan pelatihan dan pendampingan, termasuk di dalamnya adalah peserta (pelaku UKM yang akan berpartisipasi, hari dan tanggal pelaksanaan, penanggung jawab kegiatan dari pihak desa serta susunan acara dan lain sebagainya).

Pada tahap pelaksanaan (pelatihan dan pendampingan), pada tahapan ini tim Pengabdian memiliki 4 pelatihan dan pendampingan diantaranya Pelatihan dan pendampingan penguatan kelembagaan atau organisasi, pelatihan dan pendampingan Peningkatan Kualitas Produk, Harga dan Kemasan Enye-Enye, Pelatihan dan pendampingan Penggunaan Telepon Seluler (Mobile) Dalam Melaksanakan Aktifitas Kelembagaan Dan Perbaikan Kualitas Enye-Enye, Pelatihan dan pendampingan berpromosi Serta Menggunakan Pemasaran Media Sosial Berbasis Mobile Sebagai Wadah Promosi dan Refresh Pelatihan Secara Online, berikut ini penjelasan terkait pelatihan dan pendampingan:

1. Pelatihan dan Pendampingan Penguatan Kelembagaan Atau Organisasi

Pada tanggal 20 Maret 2020 Tim Pengabdian melakukan pelatihan Penguatan Kelembagaan atau Organisasi. Materi Pelatihan Penguatan Kelembagaan atau Organisasi di berikan oleh Zackharia Rialmi, S.IP., MM. Materi yang dibawakan dalam pelatihan Penguatan Kelembagaan atau Organisasi antara lain adalah pengenalan struktur kelembagaan, komponen struktur kelembagaan, dan pemahanan mengenai job desk dalam organisasi. Para peserta pelatihan diwajibkan untuk mengisi kuesioner pre test sebelum pelatihan dilaksanakan dan kuesioner post test setelah pelatihan dilaksanakan untuk mengukur keberhasilan output dari pemberian pelatihan pembentukan struktur organisasi ini. Lebih lanjut pada tangal, 21 Maret 2020 tim Pengabdian melakukan Pendampingan Penguatan Kelembagaan atau Organisasi (ke-1). Pendampingan yang dilakukan adalah terkait pembentukan struktur organisasi yang sebelumnya meski dimiliki oleh kelomok wanita pagoda, namun belum pernah di cetak dan terlihat secara fisik. Dengan adanya pendampingan pembentukan struktur organisasi (Ke-1) ini Kelompok Wanita Tani Pagoda Cigundi telah memahami bahwa struktur organisasi yang mereka miliki termasuk pada struktur organisasi lini sederhana. Disini mitra KWP sepakat untuk membagi produksi Enye-enye kedalam 4 kelompok yang berbeda, pengelompokkan didasarkan pada jarak tempat tinggal yang berdekatan. Sehingga struktur lini yang dibuat terdiri atas 1 ketua utama yaitu ibu Susi, 4 Sekretaris dan 4 Bendahara dari 4 Kelompok yang berbeda. Tim Pengabdian berinisiatif membuat desain struktur organisasi lini dari mitra KWP, Sehingga lebih mudah dilihat.

Pada tangal 28 Juli 2020, dilakukan kembali Pendampingan Lanjutan Penguatan Kelembagaan/Organisasi (Ke-2). Tim Pengabdian dan pemateri sebelumnya telah berdiskusi terkait pembentukkan 4 kelompok yang berbeda oleh mitra dan kekhawatiran tim Pengabdian mengenai perbedaan standar dari 4 kelompok ini juga telah disampaikan kepada pemateri. Pada kegiatan pendampingan ini, tim Pengabdian dan pemateri kemudian berdiskusi dengan mitra KWP terkait macam-macam struktur organisasi yang memungkinkan untuk diimplementasikan oleh mitra. mitra KWP meminta tim Pengabdian untuk merekap apa saja tugas dari masing-masing fungsi pada struktur organisasi yang baru. Tim Pengabdian berharap struktur organisasi yang baru ini dapat membawa mitra KWP untuk lebih maju, terutama karena didalamnya juga telah terdapat divisi pemasaran dan distribusi serta divisi humas. 
2. Pelatihan Dan Pendampingan Peningkatan Kualitas Produk, Harga Dan Kemasan EnyeEnye

Pada tanggal 23 Maret 2020, Tim Pengabdian melakukan Pelatihan Peningkatan Kualitas Produk, Harga dan Kemasan Enye-Enye. Materi Pelatihan Pelatihan Peningkatan Kualitas Produk, Harga dan Kemasan Enye-Enye di berikan oleh Dr. Miguna Astuti, S.Si., MM., MOS., CPM. Materi yang disampaikan antara lain adalah pemahaman mengenai pentingnya kualitas produk, penetapan harga, promosi serta bagaimana cara untuk meningkatkan kualitas produk, menetapkan harga, dan melakukan promosi. Para peserta diwajibkan untuk mengisi kuesioner pre test sebelum dilaksanakannya pelatihan dan kuesioner post test setelah pelatihan dilaksanakan untuk mengukur keberhasilan output dari pemberian pelatihan bauran produk, harga, dan promosi Enye-Enye.

Pada tangal 26 Juli 2020, Tim Pengabdian kembali melakukan pendampingan lanjutan Pendampingan Peningkatan Kualitas Produk, Harga dan Kemasan Enye-Enye (ke2). Dikarenakan PSBB yang diberlakukan pemerintah telah dilonggarkan dengan syarat, maka tim Pengabdian memutuskan untuk melkaukan pendampingan secara offline dengan datang langsung ke kampung cigundi. Mengikuti aturan dan edaran dari pemerintah Lebak Banten, Tim Pengabdian telah menyiapkan handsanitizer, masker, serta wadah untuk cuci tangan beserta sabun cair untuk disumbangkan pada mitra. Pada saat pelaksanaan pendampingan, ruang yang digunakan untuk pertemuan juga dibatasi dan telah disemprot disinfektan sebelumnya. Biasanya dalam 1 ruangan sebanyak 25 anggota KWP berdesak-desak duduk, namun pada pendampingan kali ini pengaturan duduk dibagi ketiga ruangan, sebanyak 7 orang di ruang dalam, 15 orang diruang tengah yang besar dan 10 orang diteras depan.

Pada pendampingan kali ini, Mitra KWP telah membuat contoh produk Crisp EnyeEnye yang siap santap dengan menghitung dan mencatat pengeluaran mulai dari awal sampai dengan produk jadi. Kemudian, pendampingan didahului dengan Tim Pengabdian mengajak mitra KWP untuk membuka mesin pencari pada handphone mereka masingmasing untuk melihat kisaran harga kripik sejenis yang dijual secara online. Kemudian tim Pengabdian mendampingi mitra untuk mengelompokkan mana saja biaya yang tergolong pada biaya tetap dan biaya tidak tetap.

3. Pelatihan Dan Pendampingan Penggunaan Telepon Seluler (Mobile) Dalam Melaksanakan Aktifitas Kelembagaan Dan Perbaikan Kualitas Enye-Enye

Pada Tanggal 24 Maret 2020, Tim Pengabdian Melakukan Pelatihan Penggunaan Telepon Seluler (Mobile) Dalam Melaksanakan Aktifitas Kelembagaan Dan Perbaikan Kualitas Enye-Enye. Materi Pelatihan Penggunaan Smart Mobile Phone Dalam Melaksanakan Kegiatan kelembagaan serta perbaikan enye-enye yang terdiri dari Bauran Produk, Harga dan Promosi di berikan oleh Nurhafifah Matondang, S.Kom, MM., M.Ti. Materi yang disampaikan antara lain adalah pengenalan fitur-fitur dan kegunaan yang ada di smart mobile phone untuk kegaiatan bauran produk, harga, dan promosi. Para peserta diwajibkan untuk mengisi kuesioner pre test sebelum dilaksanakannya pelatihan dan kuesioner post test setelah pelatihan dilaksanakan untuk mengukur keberhasilan output dari pemberian pelatihan penggunaan smart mobile phone dalam melaksanakan kegiatan bauran produk, harga dan promosi.

Pada tanggal 01 Agustus 2020, Tim Pengabdian melakukan Pendampingan Penggunaan Telepon Seluler (Mobile) dalam Melaksanakan Aktifitas Kelembagaan dan Perbaikan Kualitas Enye-Enye dalam Melaksanakan Kegiatan Bauran Produk, Harga dan Promosi (ke-1). pendampingan materi lanjutan pelatihan materi mengenai penggunaan smart mobile phone dalam melaksanakan kegiatan bauran produk, harga, dan promosi dilakukan oleh Nurhafifah Matondang, S.Kom, MM., M.Ti secara online melalui aplikasi conference platform zoom kepada mitra untuk mendampingi mitra secara spesifik dan 
lebih detail mengenai bagaimana pengaplikasiaan bauran produk, harga, dan promosi berbasis smart mobile phone dan meninjau kembali apakah materi yang diberikan pada pertemuan sebelumnya sudah dimengerti dengan baik bahkan dapat diaplikasikan oleh mitra.

Pada tanggal 02 Agustus 2020, Tim Pengabdian melakukan Pendampingan Penggunaan Telepon Seluler (Mobile) dalam Melaksanakan Aktifitas Kelembagaan dan Perbaikan Kualitas Enye-Enye dalam Melaksanakan Kegiatan Bauran Produk, Harga dan Promosi (ke-2). Pendampingan diberikan kepada mitra oleh Nurhafifah Matondang, S.Kom, MM., MTI secara online melalui aplikasi conference platform zoom kepada mitra untuk me-review dan meninjau kembali apakah materi yang diberikan pada pertemuan sebelumnya sudah dimengerti dengan baik bahkan dapat diaplikasikan oleh mitra. Mitra diminta untuk mencoba ulang dengan membuka wesite-website yang sebelumnya telah disampaikan dalam pelatihan. Tim Pengabdian juga menanyakan dan menginformasikan agar jangan lupa mitra KWP dapat memanfaatkan mobile (handphone) untuk kegiatan ini.

4. Pelatihan Dan Pendampingan Berpromosi Serta Menggunakan Pemasaran Media Sosial Berbasis Mobile Sebagai Wadah Promosi, Berikut Ini Penjelasan Terkait Pelatihan Dan Pendampingan

Pada Tanggal 25 Maret 2020, Tim Pengabdian melaksanakan Pelatihan Berpromosi Serta Menggunakan Pemasaran Media Sosial Berbasis Mobile Sebagai Wadah Promosi. Materi Pelatihan Penggunaan Media Sosial Berbasis Mobile Sebagai Wadah Promosi Enye-Enye di berikan oleh Dr. Miguna Astuti, S.Si., MM., MOS., CPM. Materi yang disampaikan antara lain adalah pemahaman tentang promosi dan media sosial serta betapa pentingnya promosi melalui sosial media bagi suatu bisnis. Para peserta diwajibkan untuk mengisi kuesioner pre test sebelum dilaksanakannya pelatihan dan kuesioner post test setelah pelatihan dilaksanakan untuk mengukur keberhasilan output dari pemberian pelatihan penggunaan smart mobile phone dalam melaksanakan kegiatan bauran produk, harga dan promosi.

Pada Tanggal 08 Agustus 2020, Tim Pengabdian melakukan Pendampingan Berpromosi Serta Mneggunakan Pemasaran Media Sosial Bebasis Mobile Sebagai Wadah Promosi (ke-1). Pendampingan Penggunaan Media Sosial Berbasis Mobile sebagai Wadah Promosi Enye-Enye (ke-1) lanjutan di berikan oleh Dr. Miguna Astuti, S.Si., MM., MOS., CPM. pendampingan dilakukan secara online kepada mitra kegiatan melalui aplikasi zoom. pendampingan dilakukan untuk memastikan mitra mampu melakukan promosi Enye-Enye di sosial media khusunya instagram dengan caption yang menarik dan relevan dengan produk. Tim Pengabdian juga menanyakan dan menginformasikan agar jangan lupa mitra KWP dapat memanfaatkan Media Sosial untuk kegiatan ini.

Lebih lanjut Pada tanggal 09 Agutus 2020, Tim Pengabdian melakukan Pendampingan Online Penggunaan Media Sosial Berbasis Mobile sebagai Wadah Promosi Enye-Enye (ke-2). Pendampingan Penggunaan Media Sosial Berbasis Mobile sebagai Wadah Promosi Enye-Enye (ke-2)lanjutan di berikan oleh Dr. Miguna Astuti, S.Si., MM., MOS., CPM dilakukan secara online kepada mitra kegiatan melalui aplikasi zoom. Pendampingan materi lanjutan ke- 2 ini dilakukan dengan tujuan kepada mitra untuk mereview dan meninjau kembali apakah materi yang diberikan pada pertemuan sebelumnya sudah dimengerti dengan baik bahkan dapat diaplikasikan oleh mitra. Tim Pengabdian juga menanyakan dan menginformasikan agar jangan lupa mitra KWP dapat memanfaatkan sosial media untuk kegiatan ini.

5. Refresh Pelatihan secara Online.

Berhubung dengan adanya perpanjangan PSBB efek Covid-19. Tim Pengabdian melakukan refresh berbagai pelatihan pada tanggal 25 Juli 2020 diantaranya Refresh 
Pelatihan (Online) Pembentukan Struktur Organisasi, Refresh Pelatihan (Online) Bauran Produk, Harga dan Promosi Enye-Enye, Refresh Pelatihan (Online) Penggunaan Smart Mobile Phone dalam melaksanakan kegiatan bauran produk, harga dan promosi, Refresh Pelatihan (Online) Penggunaan Media Sosial berbasis Mobile sebagai Wadah Promosi Enye-Enye. Refresh materi pembentukan struktur organisasi oleh Zackharia Rialmi, S.IP., MM; bauran produk, harga, dan promosi Enye-Enye oleh Dr. Miguna Astuti, S.Si., MM., MOS., CPM; penggunaan smart mobile phone dalam melaksanakan kegiatan bauran produk, harga, dan promosi oleh Nurhafifah Matondang, S.Kom, MM., MTI; dan penggunan media sosial berbasis mobile sebagai wadah promosi Enye-Enye oleh Dr. Miguna Astuti, S.Si., MM., MOS., CPM secara online via zoom dengan tujuan untuk me-review kembali materi yang sudah disampaikan sebelumnya

Tahap Evaluasi Kegiatan Pelatihan Dan Pendampingan, Kegiatan pelatihan dan pendampingan dalam rangka “PKM Bagi Kelompok Wanita Pagoda Penghasil 'Enye-Enye' Melalui Sosial Media Marketing Berbasis Mobile Di Kampung Cigundi, Lebak, Banten Dalam Rangka Membantu Keterbatasan Ruang Gerak Selama Pandemi Covid-19" telah dilaksanakan pada bulan Maret-Agustus 2020. Kegiatan ini dilaksanakan setelah mendapatkan surat izin melaksanakan PKM dari Mitra Pengabdian yaitu Kelompok Wanita Pagoda. Adapun Pelaksanaan Program Kemitraan Masyarakat tersebut berjalan dengan baik dan lancar, jauh melebihi ekspetasi awal dari sisi kehadiran peserta serta antusiasme peserta. Acara dijadwalkan mulai pada pukul 10.00 WIB, Namun peserta telah hadir sejak pukul 09.00 WIB, dan berakhir pada pukul 15.00 WIB. Kegiatan pelatihan sendiri telah selesai pada pukul 14.00.

Di awal kegiatan, peserta langsung diberikan kuisioner awal sekaligus pada saat tanda tangan daftar hadir, dan selanjutnya kuisioner diberikan pula setelah selesainya acara untuk mendapatkan perbandingan jawaban atas dampak Pelaksanaan Program Kemitraan Masyarakat. Jumlah peserta atau Kelompok Wanita Pagoda Sebanyak 25 Orang atau Responden. Berikut ini tabel evaluasi kegiatan diantaranya kegiatan penguatan kelembagaan, Kegiatan Peningkatan Kemampuan Mitra dalam Berpromosi serta Menggunakan Pemasaran Media Sosial Berbasis Mobile Sebagai Wadah Promosi, Peningkatan Kualitas Produk, Harga dan Kemasan Enye-Enye, dan Penggunaan Telepon Seluler (Mobile) dalam Melaksanakan Aktifitas Kelembagaan dan Perbaikan Kualitas Enye-Enye, sebagai beikut:

Evaluasi kegiatan program PKM ini dapat dilihat sebagai berikut:

a. Tim Pengabdian menargetkan peningkatan pengetahuan mitra terkait kelembagaan sebesar 60\%. Sebelum diadakannya kegiatan PKM, pengetahuan mitra terkait kelembagaan terlihat hanya mencapai $16 \%$ kemudian, setelah dilakukannya kegiatan PKM pengetahuan mitra terkait kelembagaan meningkat hingga mencapai $88 \%$.

b. Tim Pengabdian menargetkan menargetkan peningkatan pengetahuan mitra terkait produk, harga, dan kemasan sebesar 75\%. Sebelum diadakannya kegiatan PKM pengetahuan mitra terkait produk, harga, dan kemasan terlihat hanya mencapai $28 \%$ kemudian, setelah dilakukannya kegiatan PKM pengetahuan mitra terkait produk, harga, dan kemasan meningkat hingga 92\%.

c. Tim Pengabdian menargetkan menargetkan peningkatan pengetahuan mitra terkait promosi sebesar 75\%. Sebelum diadakannya kegiatan PKM pengetahuan mitra terkait promosi terlihat hanya mencapai 32\% kemudian, setelah dilakukannya kegiatan PKM pengetahuan mitra terkait promosi meningkat hingga $84 \%$.

d. Terkait job desk dalam struktur orgnisasi, sebelum diadakannya kegiatan PKM keterampiran mitra terdapat tidak satupun yang mengetahui dan memiliki jobdesk, 84\% anggota KWP tidak mengetahui dan memiliki terkait struktur organisasi/kelembagaan, hanya $16 \%$ yang mengetahui dan memiliki struktur jabatan. Setelah dilakukannya kegiatan PKM ketemapilan mitra terkait kelembagaan (jobdesk) meningkat diantaranya terdapat $26 \%$ yang mengetahui dan memiliki jobdesk, 32\% mngetahui dan memiliki struktur organisasi dan $12 \%$ tidak mengetahui arti jobdesk dan struktur organisasi hal ini disebabkan oleh ketidak hadirannya pada saat pelatihan dan pendampingan. 
e. Telah diperolehnya Enye-Enye berbentuk keripik (snack) siap santap dengan beragam rasa yang dikemas secara modern dengan merek dan harga yang menarik

f. Meningkatnya keterampilan mitra dalam menggunakan penggunaan telepon seluler yang sebelumnya ditargetkan oleh tim Pengabdian sebesar $70 \%$. Sebelum dilakukannya kegiatan PKM keterampilan mitra terkait penggunaan telepon seluler hanya mencapai 28\% kemudian setelah dilakukannya kegiatan PKM keterampilan mitra terkait penggunaan telepon seluler meningkat tingga 84\%

g. Meningkatnya keterampilan mitra dalam kualitas pelaksanaan kelembagaan dan manajemen yang sebelumnya ditargetkan oleh tim Pengabdian sebesar 70\%. Sebelum dilakukannya kegiatan PKM keterampilan mitra terkait kualitas pelaksanaan kelembagaan dan manajemen hanya mencapai 16\% kemudian setelah dilakukannya kegiatan PKM keterampilan mitra terkait kualitas pelaksanaan kelembagaan dan manajemen meningkat tingga $88 \%$

Dengan adanya pelatihan dan pendampingan seperti ini mulailah berkembang untuk meningkatkan pendapatan mitra yang diperoleh mulai dari pengemasan, bentuk yang disertai varian baru yang dikemas seceperti snack anak-anak. KWP membuat enye-enye dari $10 \mathrm{~kg}$ singkong. Setelah melalui proses hingga dilakukannya perbandingan, yang sebelumnya $10 \mathrm{~kg}$ Enye-Enye setengah jadi (belum digoreng) hanya jadi Perkemasan butuh 2,5kg singkong/ Rp.15.000/kemasan. Jadi untuk 10 singkong KWP hanya memiliki pendapatan Rp. 60.000 melalui perhitungan $(10 \mathrm{~kg} / 2,5 \mathrm{~kg}) \times 15.000=$ Rp.60.000. namun setelah dibuat menjadi Crips Enye-Enye dengan $10 \mathrm{~kg}$ Singkong dapat memberikan peningkatan pendapatan. Dimana sebelumnya pendapatan dari $10 \mathrm{~kg}$ singkong hanya menghasilkan Rp.60.000, namun setelah dibuat menjadi Crips Enye-Enye (ukuran besar) pendapatan menjadi Rp. 236.500 (Rp. 2.750 x 86 pcs). Sehingga peningkatan pendapatan kelompok wanita pagoda mencapai 294\% ((Rp.236.500 Rp.60.000)/Rp.60.000 x 100).

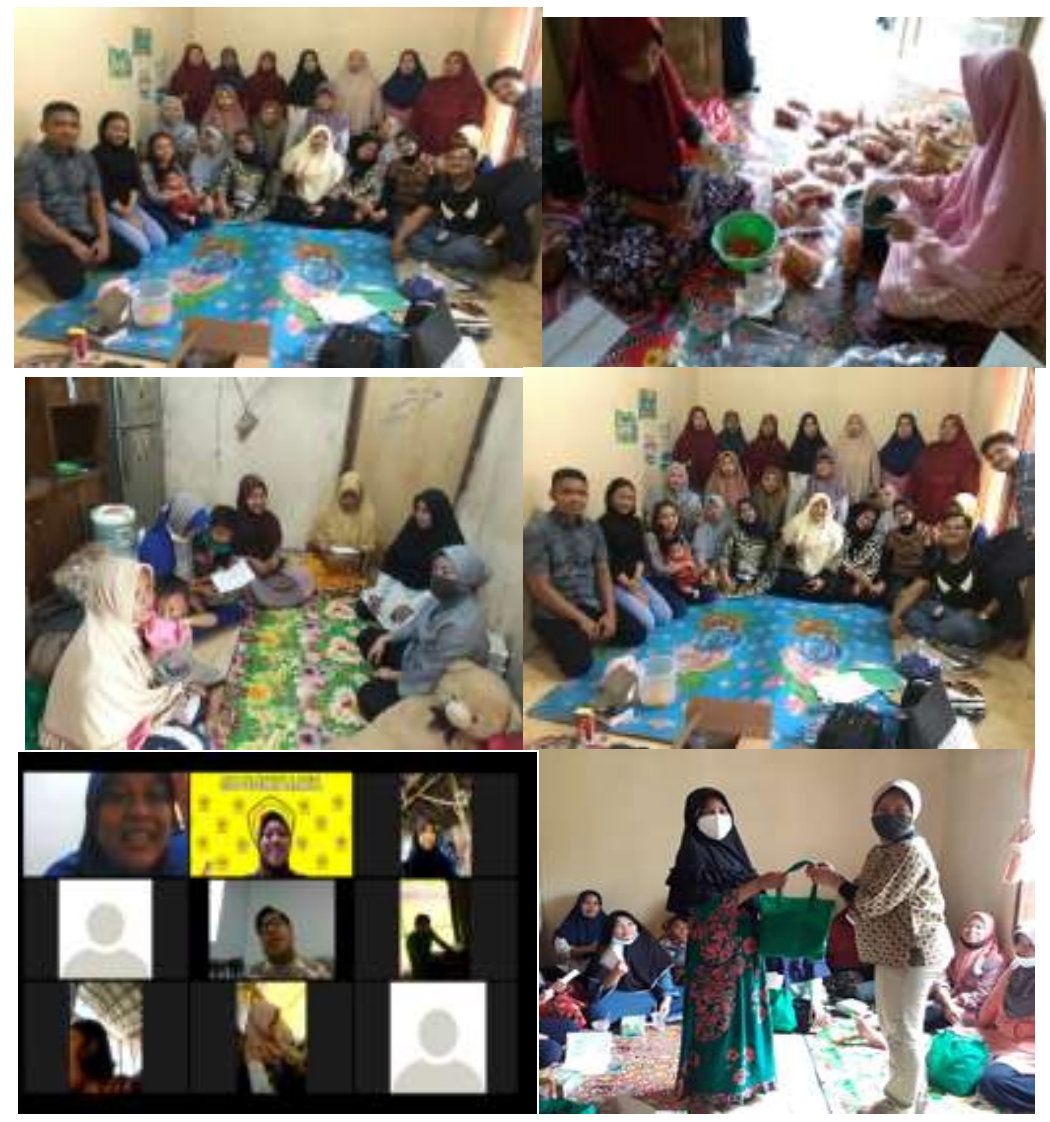

Gambar 1. Dokumentasi Selama Pelatihan dan Pendampingan Tim Program Kemitraan Masyarakat Bersama denngan Kelompok Wanita Pagoda 


\section{KESIMPULAN}

Kesimpulan Yang Dapat Diperoleh Dari Pelaksanaan Program Program Kemitraan Masyarakat “PKM Bagi Kelompok Wanita Pagoda Penghasil 'Enye-Enye' Melalui Sosial Media Marketing Berbasis Mobile Di Kampung Cigundi, Lebak, Banten Dalam Rangka Membantu Keterbatasan Ruang Gerak Selama Pandemi Covid-19" adalah :

1. Tingkat partisipasi yang tinggi dari pihak kantor desa Mekaragung dan masyarakat yang memiliki usaha UMKM yang mendukung sepenuhnya atas program Program Kemitraan Masyarakat. Hal ini terlihat dari kesediaan Kelompok Wanita Pagoda untuk memfasilitasi acara serta terlihat pula dari antusias kedatangan peserta pada saat pelatihan dan pendampingan.

2. Pelatihan dan Pendampingan yang dilaksanakan berjalan dengan dan memiliki banyak bertambahnya pengalaman serta tingginya semangatnya Ibu-Ibu Kelompok Wanita Pagoda yang membuat tim Pengabdiansemakin semangat untuk memberikan materi berkelanjutan.

3. Meningkatnya pengetahuan mitra sebesar $88 \%$ yang didukung oleh kelembagaan, kualitas produk, harga dan kemasan, kegiatan promosi.

4. Meningkatnya keterampilan mitra sebesar $86 \%$ yang didukung oleh tersusunnya struktur organisasi, Diperolehnya Enye-Enye berbentuk keripik (snack) siap santap dengan beragam rasa yang dikemas secara modern dengan merek dan harga yang menarik, penggunaan telepon seluler, dan Kualitas pelaksanaan kelembagaan dan manajemen

5. Meningkatnya pendapatan anggota KWP $>100 \%$ yang sebelumnya menjual produk stengah jadi (mentah) hanya memiliki pendapatan sebesar Rp.60.000 dengan 10kg singkong. Namun setelah dilakukannya pelatihan dan pendampingan dengan merubah menjadi makanan siap santap memperoleh pendapatan sebesar Rp.179.000 dengan berbahan 10kg singkong.

\section{UCAPAN TERIMA KASIH}

Penulis mengucapkan terima kasih kepada:

1. Direktorat Riset dan Pengabdian Masyarakat (DRPM RISTEK DIKTI)

2. Universitas Pembangunan Nasional Veteran Jakarta

3. Mitra Kelompok Wanita Pagoda

4. Pihak-Pihak Lain Yang Terkait Dalam Program Kemitraan Masyarakat Ini.

\section{DAFTAR PUSTAKA}

Afandy, A. (2010). Perencanaan Portofolio Aplikasi mendatang Berdasarkan Strategi Bisnis PT. Krakatau Industrial Estate Cilegon Unit Otonom Krakatau Steel Building Management. Surabaya.

Ali. (2019, November 07). UMKM di Lebak Didorong Terus Meningkat. Retrieved from Banten News.co.id: https://www.bantennews.co.id/umkm-di-lebak-didorong-terus-meningkat/

Alimudin, A., \& Sasono, A. D. (2015). Peningkatan Daya Saing Produk Konveksi Usaha Kecil Berbasis Iptek Di Desa Tri Tunggal Kecamatan Babat Lamongan. Yogyakarta: Prosiding Seminar Nasional Teknologi Terapan SV UGM.

Antara. (2020, Februari 23). Singkong Menjadi Andalan Petani Lebak. Retrieved from Medcom.id: https://www.medcom.id/ekonomi/mikro/RkjBV7Vk-singkong-jadi-andalan-petani-lebak

Darussalam. (2018, Maret 04). 80,45 Persen Pengguna Internet di Banten Hanya untuk Aktivitas di Medsos. Retrieved from Banten Hits: https://bantenhits.com/2018/03/04/8045-persenpengguna-internet-di-banten-hanya-untuk-aktivitas-di-medsos/

Febriyantoro, M. T., \& Arisandi , D. (2018). Pemanfaatan Digital Marketing Bagi Usaha Mikro, Kecil Dan Menengah Pada Era Masyarakat Ekonomi Asean. Jurnal Manajemen Dewantara, Vol.1 No.2 Hlm.62-67.

Gangeshwer. (2013). E-Commerce or Internet Marketing: A BusinessReview from Indian Context. International Journal of $u$ - and e-service, science and technology, pp. 187-194.

Ghozali Khakim. (2011). Pembuatan Protofolio Aplikasi Mendatang pada Perusahaan Jasa Konstruksi. Jurnal Sistem Informasi, Vol.4 No.1 Hlm. 28-36. 
Nurhanisah, Y. (2019, Maret). Penggunaan Internet Tinggi, Berkah Bagi Indonesia. Retrieved from Indonesia Baik: http://indonesiabaik.id/infografis/pengguna-internet-tinggi-berkah-bagiindonesia

Nurmalasari, D. (2020, Juni). 7 Hal yang UKM Perlu Pahami untuk Meningkatkan Akses Pasar. Retrieved from UKM Indonesia: https://www.ukmindonesia.id/baca-artikel/287

Pradipta, Y. G. (2018). Penggunaan Internet Sebagai Media Promosi UMKM Harmoni di Desa Kembangan Baki Sukoharjo. Surakarta: Universitas Muhammadiyah Surakarta. 